\title{
In Omnia Paratus: Of War, Conflict, and International Law in the Contemporary World System
}

\author{
Scott Nicholas Romaniuk (Note 1) \\ School of Politics and International Relations, University College Dublin \\ Belfield, Dublin 4, Ireland \\ Tel: 353-1-716-8303; Fax: 353-1-716-1171Ｅ-mail: Scott.N.Romaniuk@gmail.com \\ www.ucd.ie/SPIRe \\ Joshua Kenneth Wasylciw (Note 2) \\ Department of Political Science, University of Calgary \\ 2500 University Drive, N. W., Calgary, Canada \\ Tel: 403-797-2445; Fax: 780-685-2287 E-mail: Wasylciw@gmail.com \\ Christopher Douglas Mott (Note 3) \\ School of International Relations, University of St. Andrews \\ College Gate, North Street, St. Andrews, Fife KY16 9AJ, United Kingdom \\ E-mail: Tarkhan.Mott@gmail.com
}

\begin{abstract}
According to Hobbesian theory, no cure for conflict or violence can ever exist. As a result, we live in a world of perpetual anarchy and conflict. However, the reasons for this anarchy have remained a contentious point of debate, particularly among scholars of political theory. Using the current war in Iraq and Russia's war with Georgia in 2008, this article examines the chaotic state of the contemporary world system. In doing so, it applies, compares, and contrasts the theories presented in Thomas Hobbes' Leviathan and John Locke's The Second Treatise of Civil Government. Through this analysis, it is shown that Lockean theory is inadequate in explaining the anarchic state of the international system. Beyond the comparison of the two theorists addressed in this article, a brief exploration is also made of the inherent shortcomings of international law as a system that seeks to maintain order. Questions are raised regarding the efficacy and legality of the United States' second invasion of Iraq, as well as considerations for the larger impact that the war ultimately makes on the paradigm of international law.
\end{abstract}

Keywords: Anarchy, Authoritarian, Conflict, Imperialism, Individual, Iraq

\section{Introduction}

All mankind [...] being all equal and independent, no one ought to harm another in his life, health, liberty or possession.

\section{— John Locke, Second Treatise of Government}

The state of nature is a state of war of all against all [...] (bellum omnium contra omnes)

\section{-Thomas Hobbes, Leviathan}

The contemporary world system is one in which conflict is ever ensuing and constantly increasing. In Iraq, Afghanistan, Sudan, Chechnya, Georgia, and Israel-Palestine, to name a few of the many far-reaching war zones of today, war and conflict continuously rage. In each instance inter alios, violence claims the lives of countless innocents and combatants alike on a daily basis. While conflicts such as those mentioned above oftentimes appear seemingly out of nowhere, they are not, as many might suggest, inexplicable phenomena of our current and complex geopolitical constellation.

Thomas Hobbes' Leviathan and John Locke's The Second Treatise of Civil Government offer order to anarchy found deeply ingrained in the contemporary world system. In spite of the varying points of view deemed intellectually profitable in this field of scholarly analysis, this article presents the argument that Hobbesian theory retains a greater capacity to provide clear, concise, and reasonable argumentation for the anarchic 
geopolitical order in which we live.

The aforementioned thesis is evidenced pro hac vice by comparing and contrasting Hobbesian and Lockeian perspectives on the authority of the state, using the incursion in Iraq, and to a lesser-extent Russia's war with Georgia in 2008, as bases of analysis. This analytical relationship is supplemented by an examination of the basic state of nature, using the situation in Iraq as its foundation, while employing morality as a variable. The final section considers the inherent problems in Locke's argument, offering a definition of such problems.

\section{War, not Peace}

\subsection{Social Theory of Law: An International Order?}

There exist considerable points of departure regarding the purpose and ability of international law as a body of laws, regulations, and accepted practices, which differ from nation to nation. Even though international law is developed and agreed upon by the various state actors that comprise the international system, not all nations comply with the order that international law establishes, or ultimately seeks to establish.

While many within the international community petition for all nations to be held accountable to the largely accepted - though ever-evolving - framework of international law, the task is not always easy or necessarily possible to achieve. By and large, it has been demonstrated that force is an essential component through which state compliance of the emerging international order can be ensured. Political, cultural, social, and economic issues are also sharp imperatives that play an immense role regarding the recognition and compliance of international law. In some cases, theocratic and religious currents have greatly affected the execution of the international legal process as well. In other cases, the effects of international legal arguments have been perceived as undemocratic. An even greater problem lies herein, when the tenets of international law impede upon the interests and securities of sovereign states.

Through a high degree of abstraction and generalization, international law is constantly adjusting to new geopolitical realities, and continuously calls for its own establishment as the new and acknowledged organizing principle in an ever-changing and expanding global community (Kawaguchi, 2003). Of chief importance, is the assessment of 'abstract' and 'general'. Given the ambiguity over the ultimate goal or goals of international law, there is one prevalent question that needs to be broached: Is international law a positive condition of peace and co-operation in the international system or is it merely a mechanism with which to achieve the containment and sublimation of violence, conflict, and war? (Social Theory of Law, 2004).

Inside the intellectual halls of ancient Athens, the original notions of international law developed with Plato, who argued that, "the individual soul and the city-state are organized by the same principles, aiming for equilibrium (Social Theory of Law, 2004). What began in the $17^{\text {th }}$ century as an organized set of principles referred to as the 'micro-macrocosm' relation - interactions of various actors on a greater scale - was eventually referred to through the use of the term cosmopolitanism by the $18^{\text {th }}$ century. Social contract theory established its roots within the dilemma of achieving international order among states in the world system. The dilemma inherently included problems of addressing state sovereignty, laws, social order, and political stability (Social Theory of Law, 2004).

During the $18^{\text {th }}$ century, an overlap of equal state-power with modern international law was observed. Hobbes' paradigm for addressing the issue of a greater social, political, and legal order in tandem with the rise of states of equal power, was a radical departure from other social contract theorists of the time. Hobbes argues the need for a super-agency to manage states that will forever place their own interests above the interests of all others in the world system. In this regard, states should be seen as mutually distrustful, and through misanthropic attitudes, facilitators of a volatile system built on high probabilities of violence, conflict, and war. As a result, modern international law might be seen as the unfolding of a new and highly revered dispensation, though it has failed to act as such.

The issues then facing the emerging paradigm of international law resembles much of the same that the system faces today. Consider the 'Interaction Variables Model' in Figure 1. as a depiction of the contemporary international system. This diagram illustrates the independent and dependent variables as they exist in the contemporary realm of the international system. Though it does not resemble a comprehensive depiction of all interactions within this system, it offers a general impression of the variables operating within the world structure, and that contribute to a state of nature.

The conceptualization of systems and actions in the manner illustrated through the 'Interaction Variables Model' creates a nuanced analytical vantage point. It allows for a greater understanding of the various dynamics and complexities of the independent and dependent variables that are found interacting within the international 
system. Having considered the interplay between components within the system, including state actors, a portrait of interaction within the context of Hobbesian and Lockeian theory becomes clearer.

\subsection{The Laws of Conduct: America into Iraq}

When the laws governing the conduct of two enemies are removed, a state of nature results. In this state of nature, war will erupt as Hobbes states; not peace as Locke argues. As Hobbes believes, contrary to Aristotle, that the level of analysis in society should be on the individual, Hobbes asserts:

[...] during the time men live without a common power to keep them all in awe, they are in that condition which is called war; and such a war as is of every man against every man. For war consisteth not in battle only, or the act of fighting, but in a tract of time, wherein the will to contend by battle is sufficiently known: and therefore the notion of time is to be considered in the nature of war, as it is in the nature of weather (Hobbes and Macpherson, 1981).

Therefore, we should consider a world in which each and every player (state actor) has a vested interest in its own security, stability, and sustainability. In essence, Hobbes has presented a portrait of the contemporary world system characterized by a mentality of essential needs through essential means. This formula dictates, not only the conduct of nations in a chaotic international system, but their aggressive interaction with one another de lege ferenda.

As a realist, Hobbes argues that when examining the international system, each individual nation will act in a manner necessary to achieve that which is in its own best interest in relation to other state actors; similar to how an individual would act in relation to other people. A necessary consideration in relation to both Hobbesian and Lockeian theory is the concept of proximity, as noted by sociologist Zygmunt Bauman, who observes that such a concept will ultimately impact our solidarity and sense of responsibility in the world. Bauman states:

Being inextricably tied to human proximity, morality seems to conform to the law of optical perspective. It looms large and this close to the eye. With the growth of distance, responsibility for the other shrivels, moral dimensions of the object blur, till both reach the vanishing point and disappear from view (Bauman, 1989).

The current situation where Americans are fighting in Iraq demonstrates this argument conclusively (Note 4). The United States (U.S.), believing at the time that invading Iraq was in its best interest, did so indifferent to the appeals of the international community to seek a solution through multilateral and peaceful means. However, with the U.S. retaining the potential to promote its self-interest - whether economically by means of natural resources, or in terms of security by means of removing an opposing authoritarian power - the U.S. chose to proceed with the United Nations (U.N.) exemplifying its lack of power in preventing any such invasion.

Locke argues that, "what state all men are naturally in, and that is, a state of perfect freedom to order their actions, and dispose of their possessions and person, as they think fit," exemplifies the perspective that peace is a reasonable expectation in the absence of government (Locke and Laslett, 1967). However, the peace and tranquility that is prevalent in Lockeian theory is absent in the present international system. According to Locke:

A state also of equality, wherein all the power and jurisdiction is reciprocal, no one having more than another; there being nothing more evident, than that creatures of the same species and rank, promiscuously born to all the same advantages of nature, and the use of the same faculties, should also be equal one amongst another without subordination or subjection, unless the lord and master of them all should, by any manifest declaration of his will, set one above another, and confer on him, by an evident and clear appointment, an undoubted right to dominion and sovereignty (Locke and Laslett, 1967).

Noting that there is no effective government in place is crucial to our interpretation of the relationship between international law and actors expected to conform to its establishments. The 2003 American-led invasion of Iraq has demonstrated a sharp and poignant departure of the respect for international law, multilateral governance, and institutionalism. How then does the concept of morality play a role in mitigating or completely preventing such an aggressive action? Simply put, morality does not exist in this context at all. Morality may be interpreted as an artificial impasse to logical pursuits, and actions undertaken out of necessity. Although it does not exist in through a realist perspective, it is still considered a variable in the equation. Acting as a 'disruptive' force in the geopolitical world, people are easily convinced of silencing "their moral misgivings in order to get certain 'jobs' done" (Jacobsen and Poder, 2008). Bauman explains that morality is capable of the following:

(1) Stretching the distance between action and its consequences beyond the reach of moral impulse; (2) exempting some 'others' from the class of potential objects of moral conduct, of potential 'faces'; (3) dissembling other human objects of action into aggregates of functionally specific traits, held separate so that the occasion for re-assembling the face does not arise and the task set for each action can be free from moral evaluation 
(Bauman, 1989).

Since many people are capable of securing their own essential needs without having to witness their actions or means, they simply are not troubled. It is much easier to be a killer and to act in cruel and malicious ways when, the perpetrator adds physical distance to the equation. However, we must consider that there is a second 'distance' active in this 'animalistic' solution: moral distance.

\subsection{The Necessity of State Power: Russia's August War}

A distinct example of the necessity of state power and security in policy-making is Russia's 2008 war in South Ossetia and Abkhazia. The conflict accelerated in intensity over a short period of time, becoming the most significant crisis in field of European security in a decade (Svante and Starr, 2009). Although the legal recognition of those two autonomous zones was held to be squarely in Georgia's sovereign territory by the international community, including the Russian Federation, it soon became apparent that the Kremlin was effectively holding both provinces as trump cards to ensure Georgian compliance with its objectives - an otherwise brilliant strategy on Moscow's part (Asmus, 2010).

Once Georgia's intentions of escaping from Russia's sphere of influence, and making a dash for the security of North Atlantic Treaty Organization (NATO) became clear, Russia disregarded its previous upholding of Georgia's recognized territorial boundaries and proceeded to launch a military strike designed to cripple Tblisi's political aspirations as well as take away the autonomous provinces (Asmus, 2010). The result was the ephemeral establishment of Georgia's autonomy.

Since neither Abkhazia nor South Ossetia had its security provided by Georgia - and in the case of Abkhazia specifically felt Georgia to be its number one threat - the provinces supported Russian action because it provided them with security. Georgia, on the other hand, could promise only little in comparison to the geopolitical contributions of Moscow, and nothing that could elevate the security of the people who lived in the provinces, even if what Russia's leadership had in mind, was decidedly illiberal.

The invasion was not only a surprise to Georgia; it was a shock to Europe, the European Union (E.U.), and the rest of the world. With the current state of world affairs, and from a liberalist point of view, what should have been considered axiomatic was not Russia's invasion itself, but rather the extent of Russia's willingness to apply crude military force against Georgia. From a realist perspective, while the former may have been unexpected, the latter was anything but. Russia's previous interventionist policies in post-Soviet states were understood by realists the world over, while its push factors were greatly misunderstood by others in the analytic community particularly those suffering from the intellectual and moral disease of liberalism.

State-deterioration and collapse is not in the best interest of realists or liberalists under any circumstance. The collapse of state-structure is in and of itself a powerful reason for conflict and for states to wage war, as is demonstrated in the case of Georgia. Intra-state conflict should always be considered far more dangerous than inter-state conflict. Since systematic consequences of state collapse reverberate far beyond the confines of the borders of the collapsed state in question, there is always sound reason for military intervention. The Georgian conflict would prove a manifestation of this sentiment, but there are alternative perspectives to the notion.

Hobbes argues that, no matter how unjust or substandard the operations of any given states are, a deficient state will always be better than the absence of state - the experiences of Yugoslavia and the Soviet Union confirm this (Hobsbawm, 1993). Hobbes would have recognized and appreciated the lessons presented in both cases. Though Russia's experience informed Moscow's decision to preserve and maintain regional security in the Caucasus even if sought through illegal means - we might well consider a fusion of the Yugoslavia and Soviet Union lessons with the recent Georgia-2008 model.

\section{War and Authority of the State}

Limiting the authority a government has over its subjects, as Locke argues, will always eventually result in the impotence of the state (Locke and Laslett, 1967). In a state of nature, in which the international system constantly exists, the state must possess absolute power as is propagated by Hobbes in order to maintain enough power to emerge victorious in war.

Consider again the current situation in Iraq. The U.S. campaign that began in 2003 may be considered a failure, not as a result of an enemy possessing superior fighting capabilities, but due to Americans' inability to accomplish what they require largely because the American government is forced to justify all of its actions and decisions to the American public. Consequently, the American people - who are not accustom to the pains of war - have became unwilling to accept anything less then immediate success. In short, The U.S. administration remains answerable to a great number of constituents. 
Not only does the American government find its power limited by the number of constituents to which it much answer, but it must also tread carefully through its conduct in war. That is, military discipline and constitutional propriety have been understood as potent ingredients in the creation of a system that prevents senior American military officers from openly articulating their own reservations and outright fears about the policies of their political superiors (Dyer, 2003). By further demanding their forces not to engage in what has otherwise been seen as 'atrocities' that naturally occur in a state of war - or at the very least not allowing their forces to use tactics similar to those used by their enemy or enemies - the U.S. is forced into a position of significant weakness. In turn, politicians have placed the onus of responsibility on U.S. military rank and file for having failed to complete objectives that were under considerable political-military paralysis from the beginning.

An authoritarian government would possess the power to use any means necessary to win in a state of war. However barbaric they may seem, their overall effect would be desirable. In this hypothetical case the Americans - with obvious advanced military capabilities - would be able to accomplish their mission in Iraq quickly. In the state of nature, Hobbes argues that all that matters is the self (Hobbes and Macpherson, 1981). Consider the following text, which takes the concept of matters a step further and applies it to perceptions of the victor and the vanquished:

It is not therefore the victory that giveth the right of dominion over the vanquished, but his own covenant. Nor is he obliged because he is conquered; that is to say, beaten, and taken, or put to flight; but because he cometh in and submitteth to the victor; nor is the victor obliged by an enemy's rendering himself, without promise of life, to spare him for this his yielding to discretion; which obliges not the victor longer than in his own discretion he shall think fit (Hobbes and Macpherson, 1981).

While this case may not appear to uphold the ideal of human rights as we should like to think ourselves and as upholding, it is precisely this deviation from a precise degree of civility or humanism that would ultimately change the nature and outcome of the war. As Hobbes states:

The sovereign is absolute over [both the conquerors and conquered] alike; or else there is no sovereignty at all, as so every man may lawfully protect himself, if he can, with his own sword, which is the condition of war (Hobbes and Macpherson, 1981).

Locke though, incorrectly claims that, "men living together according to reason, without a common superior on earth, with authority to judge between them, is properly the state of nature" (Locke and Laslett, 1967). Detrimental to Lockean belief is this 'reason' that is explained as enabling and allowing men to retain some of the power which would be incontrovertibly relinquished in a Hobbesian state. Of no less importance is the fact that Locke fails to define reason; a vitally important concept which needs clarifying prior to making such sweeping and absolutist assumption.

\section{Lockeian Shortcomings}

In addition to the major limitations within Locke's overall argument in relation to wholly submitting to an authoritarian régime - that people are innately reasonable - Locke's argumentation suffers from further weakness. He asserts that no person has the right to give up his or her own life. However, if one has given up executive rights to the state in order to, "enter into civil society, and become a member of any commonwealth, he has thereby quitted his power to [...] [resist] the commonwealth to employ his force [...] whenever he shall be called to it," then the state may demand the life of that person without violating his natural rights (Locke and Laslett, 1967).

It is precisely this idea of the state doing away with what may otherwise be considered its own, albeit living, property that causes the disputation between Locke and Hobbes over the issue of authoritarian régime. Locke fears that abuses of authoritarianism would result in a corrupt and cruel state, but he argues that the state should be allowed to demand the life of others, without violating nature.

\section{Power and Authority: A Perspective}

We might analogize the United Nations as a teacher, with all the members of the General Assembly resembling kindergarten students. In some cases, we observe intelligent students, and in other cases we observe ignorant and naïve students. On one hand we see that those 'students' less intelligent typically lack experience, and fail to realize the consequences of their actions. On the other hand, the same consequences are felt by the mature and intelligent, but less experienced students. If realism and liberalism were fused with this analogy, we would find that the most experienced students are representative of realism, whereas those merely intelligent and perhaps even mature, but not necessarily experienced, depict liberal states.

Should there be any puzzlement why the U.S. and Russia are members of the Security Council? Is it just to 
punish certain members due to the lack of experience held by others? Why should the international community be surprised to observe the same violent and anarchic system in which it exists, thrive within the very liberalist institution that was established to prevent it?

\section{Conclusion: A State of Nature or a State of Order?}

The international system is anarchic. However, the reasons for such anarchy are non constat and disputed by many within the political and analytic communities. In the preceding pages it was shown that the contemporary world system is chaotic by looking at the current war in Iraq and Russia's war with Georgia in 2008 as bases of analysis. The theories presented in Thomas Hobbes's Leviathan and in John Locke's The Second Treatise of Civil Government were applied to these situations. Hobbesian theory was shown to provide in fine a more acceptable explanation for the current international system.

First, the differences between Hobbesian and Lockeian perspectives as they relate to the authority of the state were demonstrated. Second, an examination of the basic state of nature was conducted. Third, and finally, the problems inherent in Locke's overall argument were defined in order to provide further refutation to his account. As such, it must be concluded that between the Hobbesian and Lockean models, the only reasonable way to explain international anarchy today is vis-à-vis Hobbesian theory.

Beyond the comparison of the two theorists addressed in this article, a brief exploration was made of the inherent shortcomings of international law as a system seeking to establish and maintain order. The Iraq case provides the best modern example of diminishing the U.N. as a liberal institution as well as its central covenants. It seems senseless to maintain an international legal force if a superpower or hyperpower, such as the United States, has more power than all of the United Nations combined, and seeks to repeatedly diminish the Organization's authority by way of unilateral action. Not only is America's advanced military capabilities the cornerstone of U.N. military operations, it is also the hallmark of NATO's military authority. Thus, in two decisive cases, we observe American hegemony as basis of U.N. and subsequent examples of multilateral co-operation.

In more than a single case, we find that the middle classes, that is the intermediary state powers operating within the current international system, are so inextricably linked to U.S. hegemony in nearly every corridor of the world, that there exists almost no incentive to broker competition with American interests. Simply put, the current is too strong to swim against. In the aftermath of major American-led military operations in Iraq, from 2003 onward, members of the E.U. bloc, notably France and Germany raised serious issue with their U.S. ally. While neither country participated in the post-conflict reconstruction of the area in question, neither expressed desire nor need for revisions to the current international legal framework in the interest of preventing U.S. unilateralism in the future either (Social Theory of Law, 2004).

In the spirit of Hobbesian theory, we may address the 2003 invasion of Iraq as a necessity that meant operating beyond a legally established order. The same holds true for Russia's unilateral action in Georgia too. What then may be said of the impact that the war in Iraq and Georgia have made, even if conceptually, on the paradigm of international law? In short, political ends justify illegal means. The second Iraq war redefines the inanity of international regulation of state actions in a state of nature. The sentiment is strengthened when one considers that the elimination of Saddam Hussein was in the best interest of state sovereignty, as well as other strategic interests. Though the establishment of international law created the circumstance in which no legal means existed to exorcise Saddam Hussein from power and eliminate the Iraqi threat, the U.S. simply employed less than legally accepted means as an alternative strategy to the United Nations as an inflexible and ostensibly justice-oriented, institutional order.

\section{References}

Asmus, Ronald D. (2010). A Little War That Shook the World: Georgia, Russia, and the Future of the West. New York, NY: Palgrave Macmillan.

Bauman, Zygmunt. (1989). "Hermeneutics and Modern Social Theory", in David Held and John B. Thompson (eds.): Social Theory and Modern Societies: Giddens and His Critics. Cambridge, UK: Cambridge University Press.

Cornell, Svante E. and S. Frederick Starr. (2009). The Guns of August 2008: Russia's War with Georgia. Armonk, NY: M. E. Sharpe.

Dyer, Gwynne. (2003). Ignorant Armies: Sliding into War in Iraq. Toronto, ON: McClelland \& Steward Ltd.

Hobbes, Thomas and C. Macpherson. (1981). Leviathan. New York, NY: Penguin Classics.

Hobsbawm, Eric J. (1993). Nations and Nationalism Since 1780. Cambridge, UK: Cambridge University Press. 
Jacobsen, Michael Hviid, and Poul Poder (eds.). (2008). The Sociology of Zygmunt Bauman: Challenges and Critique. Burlington, VT: Ashgate.

Kawaguchi, Kazuko Hirose. (2003). A Social Theory of International Law: International Relations as a Complex System. Leiden, Netherlands: Brill.

Locke, John and Peter Laslett. (1967). The Second Treatise of Civil Government.

"Social Theory of Law". (2004). <http://www.warwick.ac.uk/ sysdt/st12004-05.htm>.

\section{Notes}

Note 1. Scott Nicholas Romaniuk is a doctoral candidate at University College Dublin's School of Politics and International Relations. E-Mail: Scott.N.Romaniuk@gmail.com

Note 2. Joshua Kenneth Wasylciw is a graduate researcher at the University of Calgary's Department of Political Science. E-Mail: Wasylciw@gmail.com

Note 3. Christopher Douglas Mott is a doctoral candidate at University of St. Andrews' School of International Relations. E-Mail: Tarkhan.Mott@gmail.com

Note 4. On 27 February 2009, President Barack Obama promised a complete end of all combat operations in Iraq, and a comprehensive withdrawal of American troops from that country by the end of August 2010. Although this article was written during the summer in which American withdrawal is scheduled to commence, it is necessary to consider the implications that post-military reconstruction as an extension of military operations has on the argumentation presented herein.

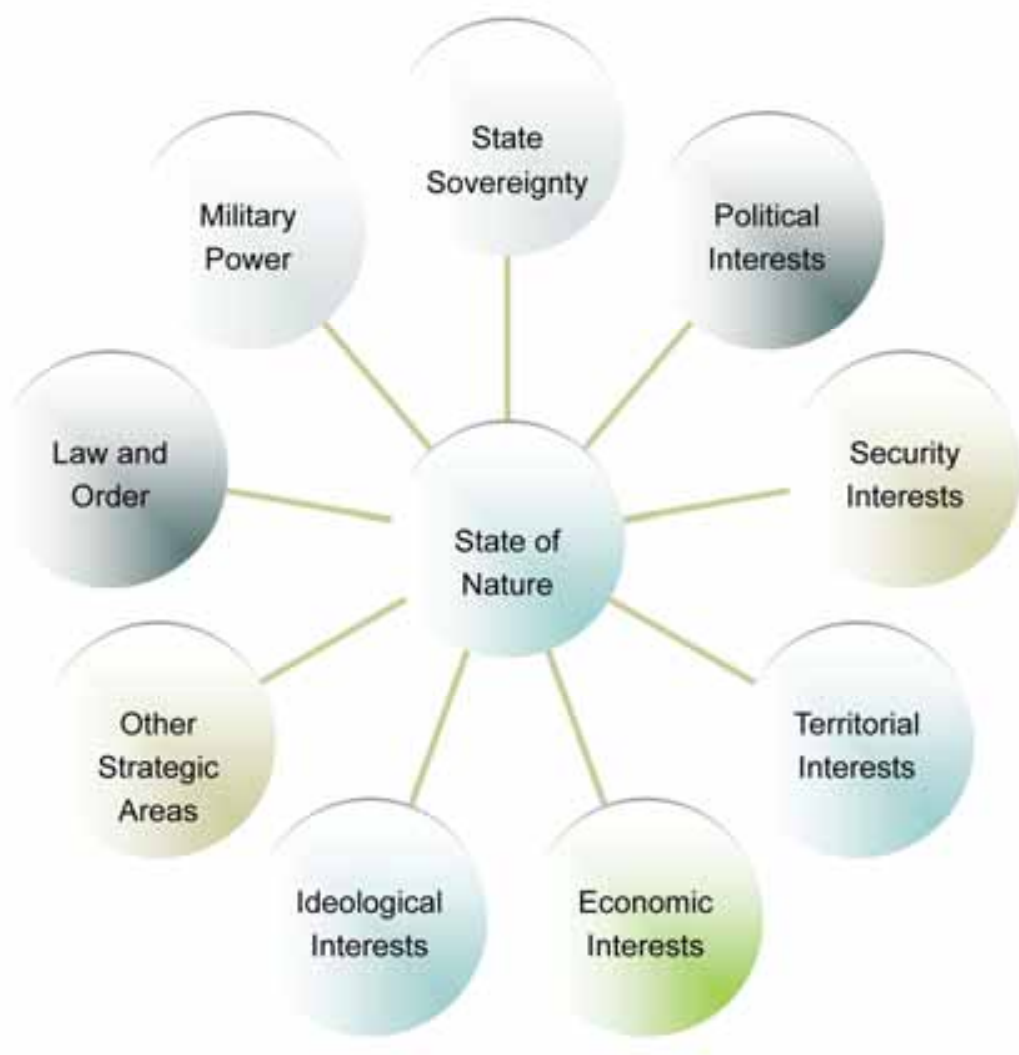

Figure 1. Interaction Variables Model 